\title{
The rise of multilevel governance for biodiversity conservation in Belarus
}

\author{
Ilona M Otto \\ Potsdam Institute for Climate Impact Research, Potsdam, Germany; \\ e-mail: banaszak@pik-potsdam.de
}

\section{Anton Shkaruba, Viktar Kireyeu}

Department of Environmental Sciences and Policy, Central European University, Budapest, Hungary; e-mail: shkarubaa@ceu.hu, kireyeu_viktar@ceu-budapest.edu

Received 5 December 2009; in revised form 16 September 2010

\begin{abstract}
We describe the emergence of multilevel policy in biodiversity governance in Belarus-a country with a strongly hierarchical and centralized political system. We analyze the biodiversity protection policies from the collapse of the Soviet Union to the present day. Our evidence is based on document analysis and in-depth interviews with representatives of key stakeholder groups, including the Belarusian government and representatives of legalized as well as banned nongovernmental organizations. We observe that the importance of local government and nonstate actors in increasing, as the government enters and implements more international programs and agreements. Although the changes have contributed to an improved monitoring of protected areas and are in general seen as positive by the majority of stakeholders, the policy innovation process taking place in Belarus is still very different from those observed in Western democracies. Many changes are introduced on an ad hoc basis and they are not supported by the development of legal standards and procedures. Furthermore, a portion of innovative legislation exists only on paper and is never enforced. In the area of biodiversity governance, effective and urgent measures are most needed to support access to information, development of formal channels of cooperation between stakeholders, and sanctioning mechanisms in cases of mismanagement.
\end{abstract}

\section{Introduction}

Biodiversity protection in Belarus has a long history. The first protected area in the modern understanding of this term was established in Belarus in 1925. However, the institutional mechanisms for biodiversity protection were developed in Soviet times and the overall style of governance has remained largely unchanged since then. Private property in its conventional form was introduced only after the collapse of the Soviet Union in 1990-91. Even now, however, privatized land is restricted to small domestic patches. Furthermore, the development of civil society institutions has been frozen for more than a decade. Nevertheless, the collapse of the Soviet Union and growing influences of international organizations have initiated the transformation of environmental policy and adoption of new policy instruments by national governments that involve supranational and subnational actors. There are, as yet, rare cases of bottom-up initiation of policy change. The governance standards originating from the European Union (EU), United Nations (UN) agencies, and other international organizations are starting to have an impact on the national legislation.

In this paper we trace the rise of the multilevel policy in biodiversity governance in Belarus. Our objective is to characterize the changes that have been introduced and the response of different administrative levels of the Belarusian governance structures, characterized by a long, highly hierarchical, tradition. We focus on the period from the collapse of the Soviet Union until the present day and we determine how changes in environmental policies emerge and develop where there is a strong centralized and hierarchical system monopolizing the political discourse. 
There is a broad range of literature investigating the implementation of new policies. The literature focuses mostly on the policy innovation process in Western democracies characterized by multiactor discourse and deliberative change. For example, Vo $\beta$ (2007) categorizes studies of policy innovations into three groups: (i) implementation studies, which argue that policies and instruments used in the design of action programs often undergo considerable change in the process of implementation, due to political programs being drafted far away from the agencies that have to implement them; (ii) policy diffusion and transfer studies track policies as they occur across various governance domains. Explanation for patterns is sought by correlating variables of governance domains with a point in time in which a policy becomes adopted. Thus leaders and laggards of the policy adoption process are identified and conditions for the innovativeness of the policy pioneers are statistically tested. Policy transfer studies focus on the transfer of policy ideas from one focal domain to another; (iii) policy learning studies view the innovation process as an accumulation of experience and know-how across several instances of policy making and focus more on general problem frames and policy goals embodied in beliefs and ideology than on instrumental aspects of the policy (Vo $\beta, 2007)$. Berry (1994), using a US example, furthermore argues that the primary factors leading to policy changes are internal political, social, and economic characteristics. However, some policies are also adopted following changes in nearby states due to regional diffusion. National communication networks also play a certain role in this process. The interactions of state officials spread the changes from adopting states to nonadopters. Deyle (1994) draws attention to the conflict and uncertainties in policy changes. Stakeholder perceptions of the consequences of different types of policy change influence the level of political conflict in a particular policy innovation. Uncertainty influences both the level of conflict and the choice of innovation process. The statutory authority held by an agency can also influence the choice of a particular innovation process. If a policy innovation requires new statutory powers, an initial legislative process is necessary.

Several studies discuss policy changes in top-down and centralized systems in Eastern Europe (Banaszak and Beckmann, 2008; Bosse, 2009; Bosse and Korosteleva-Polglase, 2009; Elander, 1997; Korosteleva, 2009; Pickvance, 1997; Zsamboki and Bell, 1997). In the context of natural resource management, Kluvánková-Oravská et al (2009) show how the combination of newly emerging institutions with the ruins of communism influences the restructuring of governance from hierarchical to multilevel structures in Central and Eastern Europe. The problem of transforming former socialistic natural resource management institutions is also addressed by Gatzweiler and Hagedorn (2002) and Chobotová (2007). For Belarus, however, with its special development path, the communist governance system is not in ruins to the same extent as in other former USSR countries, and the old institutions are trying to cope with the new reality and keep the status quo. This configuration, apparently much more pronounced in this country than in Russia, Moldova, or Ukraine, is the focus of this paper.

The paper is organized as follows. In section 2 we present the concept of multilevel governance as applied in this study, describe the data and methods used for their collection, and give background information about the development of the biodiversity conservation system in Belarus during the communist time and its subsequent transition. In section 3 we describe the new elements caused by the policy change paying particular attention to the introduction of market governance, increasing role of local communities, emergence of independent nongovernmental organizations (NGOs), and the role of international organizations and funds. In section 4 we evaluate the policy changes, including the perception of change by stakeholders, level of policy conflict, uncertainties related to the policy change, and possible future changes. Finally, in section 5 we conclude. 


\section{The analytical strategy}

\subsection{The concept of multilevel governance in biodiversity protection}

Hodgson (2004) defines institutions for biodiversity governance as systems of established and embedded social rules that structure interactions between social and ecological systems. Individual institutions are often lined together through various types of interdependencies. Environmental changes that act as a trigger for change together with an increasing density of international institutions lead to an increase in interactions between and among institutions (Young, 2002). The nature of cross-scale and dynamic relationships between ecological, economic, and social systems, as well as processes such as natural resource use intensification and commodification of natural resources, impose multilevel challenges on linkages among different actors and institutions. In practice it implies that decision-making responsibilities are often shifted down to the local level, stakeholders are encouraged to participate in decisionmaking concerning the natural resources, and efforts are undertaken to strengthen collaboration among actors at different levels (Armitage, 2008).

Hooghe and Marks (2003) refer to the process of the dispersion of central government authority both vertically and horizontally as multilevel governance. Multilevel governance can be related either to the dispersion of governmental authority to generalpurpose territorial jurisdictions with nonintersecting membership, or to special-purpose jurisdictions tailoring membership, rules of operation, and functions to a particular policy problem. This process is also referred to as polycentric governance which describes coexistence of many centers of decision making that are formally independent of each other (McGinnis, 1999; Ostrom et al, 1961). A central characteristic of multilevel governance is an increasing participation of nonstate actors in political decision making (Bache and Flinders, 2005). A few authors argue that participatory processes are a key component of multilevel governance since they contribute to legitimacy and effectiveness of governance solutions (eg Fiorino, 1989; Meadowcroft, 2002; Stirling, 2006) and can lower costs of policy implementation (Rauschmayer et al, 2009). Rauschmayer and Wittmer (2006) present evidence showing that participatory methods can support new resolutions to environmental management challenges. Although their uptake remains slow, they have been recognized as useful for improving multilevel governance. This is reflected in an increasing number of international environmental laws and regulations such as the Convention on Biological Diversity and the Aarhus Convention (Rauschmayer et al, 2009).

Following Kluvánková-Oravská et al (2009), the emergence of multilevel biodiversity governance in transition countries is demonstrated by processes such as an increasing role for market governance, decentralization, and democratization in institutions concerned with biodiversity protection. Market governance is defined as an assignment of previously collective and state property rights to specific owners by means of restitution, sale, or other forms of privatization. More broadly, market governance can be understood as a resource-allocating mechanism or measurement of efficiency through monetary criteria (Pierre and Peters, 2000). Among market mechanisms that can be applied in biodiversity governance we may find market-based instruments such as taxes, fees and charges, forms of subsidies and compensations, tradable permits, and ecolabeling (Bräuer et al, 2006). The concepts of democratization and decentralization are discussed broadly by Pickvance (1997). Democratization can be measured by the degree of inclusiveness of citizens and direct participation in decision making. It also refers to freedom of joining associations, freedom of expression, right to vote, eligibility for public office, right of political leaders to compete for support, access to alternative sources of information, free and fair elections, and dependence on institutions for making government policies based on votes and other expressions of preference (Dahl, 1971). 
Decentralization is characterized by empowering lower government levels through the range of functions they carry out, the degree of autonomy over how these functions are carried out, and the degree to which they are funded from their own resources (Pickvance, 1997).

In Central and Eastern Europe the communist period and the treatment of common property as open access resulted in overexploration of natural resources and inefficient institutional design of biodiversity governance (Kluvánková-Oravská and Chobotová, 2006). Several authors argue that multilevel governance and inclusion of nonstate actors may lead to reaching higher ecological standards and improved compliance with environmental legislation (eg Dryzek, 1997; Sabatier et al, 2005; Smith, 2003). Newig and Fritsch (2009) have undertaken a broad literature review analysis that suggests that a highly polycentric governance system composed of many agencies and levels of governance yields higher environmental outputs than monocentric governance. They take more ecologically rational decisions, improve compliance with decisions, and thus achieve better outcomes and impacts in ecological terms.

In the subsequent parts of the paper we will examine the drivers that lead to opening up the hierarchical and centralized environmental governance system in Belarus to nonstate actors and the effects of these changes. We follow the framework of analysis developed by Kluvánková-Oravská et al (2009), paying particular attention to (i) the emergence of market governance in biodiversity protection in Belarus, (ii) the process of decentralization and democratization through investigating the role of local communities and local governments, and (iii) the opening of political decision making to nonstate actors. In addition, we undertake an evaluation of these policy innovations based on Deyle (1994), who proposes to focus on the perception of change by stakeholders, the level of political conflicts, and the uncertainty that surrounds the policy change. As Deyle argues, the level of public controversy about the new policy influences the legitimacy of the process and increases the likelihood of legal challenge by one interest or another. The uncertainty (eg attributed to scientific measurement and evaluation or technological complexity underlying alternative policies) aggravates the tendency towards conflict among stakeholders.

\subsection{Data and methods}

In order to investigate the policy change process in Belarus we carried out a literature review and fourteen in-depth interviews. The literature reviewed included national and international scientific publications, reports, planning documents, and decisions and regulations of governmental and international agencies involved in biodiversity conservation in Belarus. During our literature review we identified key stakeholders and organizations involved in the development of biodiversity conservation policies or biodiversity management, and/or affected by management measures at national parks, in particular at Belavezhskaya Pushcha. Afterwards we arranged appointments and carried out in-depth interviews with those officials willing to talk to us from the ministries involved in biodiversity governance, management of the Belavezhskaya Pushcha National park, NGO representatives, local authorities from districts where the Belavezhskaya Pushcha National Park is located, and scientists from the Belarusian Academy of Sciences and Belarus State University. The Belavezhskaya Pushcha National Park was chosen as a reference case in our research because the uniqueness of the park is recognized internationally and has a relatively long record of cooperating with international organizations. It has been on the UNESCO World Heritage List since 1979 and it is still the only nature protected area in Belarus included in the list. Additionally, at the time the research was carried out, several 
international media and Internet websites reported mismanagement of the park's resources, and conflicts between its administration, local population, and NGOs.

A detailed list of interviewees is presented in table 1. Most of interviews were carried out in July 2008; however, in a few case we completed the interviews a few months later depending on the availability of our interviewees and our ability to travel to Belarus. One interview with a representative from the Ministry of Natural Resources and Environmental Protection was carried out earlier - in January 2008 - in a pilot project recognizing the potential and importance of the research.

Table 1. List of interviews.

\begin{tabular}{|c|c|c|}
\hline Organization & Positions & $\begin{array}{l}\text { Number Date } \\
\text { of persons } \\
\text { interviewed }\end{array}$ \\
\hline
\end{tabular}

\begin{tabular}{llll}
\hline Ministry of Forestry & $\begin{array}{l}\text { A representative of the national } \\
\text { forestry company 'Belgosles' }\end{array}$ & 1 & October 2008 \\
Ministry of Natural & $\begin{array}{l}\text { Representatives of the Ministry } \\
\text { related to the management of } \\
\text { Resources and }\end{array}$ & 3 & January 2008, \\
Environmental & international projects, biodiversity & & July 2008
\end{tabular}

Environmental conservation, and climate change

Presidential

Management

Department

Representative of the administration of the national park 'Belavezhskaya Pushcha'

National Academy of Sciences

Research officers of the Conservation 3 Sector of the Research Center for July 2008 Biological Resources designing management plans for protected areas, including Belavezhskaya Pushcha

Ministry of Education

Researchers at the Belarusian State University involved in strategic planning for biodiversity conservation

Local Authorities

Representatives of Kamianec District 3 Council and Pruzhany District

Executive Committee

NGOs
Representatives of the initiative group 3
'Belavezhskaya Pushcha-21st
Century', NGO 'Ecopravo', and NGO
'Geographical Society of Belarus' July 2008,

July 2008,

November 2009

2

October 2009

July 2008

July 2008,

May 2009

The interviews were divided into two sections: (i) the new processes observed by the interviewees in biodiversity governance in Belarus and (ii) the evaluation of these changes by the interviewees. The responses from interviewees have been furthermore divided in regard to the research question of the study and compared with each other and the specific context of the research.

\subsection{Historical development of biodiversity governance in Belarus}

The history of building a communist state started in Belarus in 1917. In 1921, under the Peace of Riga, Western Belarus became a part of Poland, while the Central area remained a part of the Belarusian Soviet Socialist Republic, and Eastern Belarus until 1924-26 belonged to the Russian Soviet Federal Republic. In Central and Eastern Belarus all the privately and community owned land and forests were nationalized immediately after the communists took control. 
There is a large body of literature about the history of biodiversity conservation in the Soviet Union (eg Mnatsakanian, 1992; Weiner, 1999). The first protected area in Soviet Belarus, Biarezinsky Reserve (Zapavednik), was established in 1925. For this, thirty farms were removed from the protected area in 1928 - 30 (Stavrosky and Kovaliov, 1996), although land-use and property conflicts were not officially reported. There has always been tension between different governmental institutions sharing in the use of nature resources and environmental protection. The growth of the socialistic economy was an absolute priority, as it was considered important not only to support growing welfare costs and military expenses, but also to demonstrate the superiority of the socialist social and economic model. Ministries and government agencies had always put pressure on environmental resources. After the Second World War, when both the national economy and general population urgently needed substantial supplies of construction materials, the Biarezinsky Reserve became an arena of large-scale logging operations. In 1951, on an initiative of the USSR Minister of Forestry, the reserve was abolished and it was renewed only in 1959. The Belavezhskaya Pushcha National Park, although it was recognized and sustained as a natural protected park, had been drastically modified and transformed into a game reserve extensively used by top party officials (Kozulko, 2005).

The situation improved slightly by the mid-1970s when it was firmly established that natural protected areas were sites for conservation, research, and learning, and the government did not make serious attempts to use them for other purposes. Most reserves possessed some tourist infrastructure, but this was not well developed. Principles of management were in an early stage of development until the mid-1970s, and since then they have not substantially changed. Table 2 presents detailed profiles of existing categories of protected areas in Belarus.

The only quasi-nongovernmental actors involved in environmental decision making in the Soviet times were researchers, since universities and research institutes were controlled by the Party. The basing of all major decisions on scientific evidence was deeply rooted in the technocratic communist ideology. 'Wise' use of nature was opposed to the capitalist profit-driven ways (Mnatsakanian, 1992). Scientists have always been consulted before new decision and policies on biodiversity conservation are adopted, although this has tended to become ritualized rather than actually consultative. In the Soviet decision-making process, the USSR Academy of Science and its regional branches were very important institutions, and partially substituted the role that NGOs play in Western societies.

In 1990 land property rights were reestablished in Belarus (Act of Land Property Rights, 1993; Land Code, 1990). However, the size of land plots and eligible ways of using them were restricted. The situation has not changed much since then, and in the second national referendum in November 1996 any further developments of the land market were banned by an overwhelming majority of voters (Sakovich, 2005). Under the current legislation and administration practices, land can be privatized only for limited agricultural use, and large plots can be given away only under long-term rent. Privately owned land is allowed in protected natural areas, with the exception of zones of strict protection in zapavedniks and national parks, but its use is restricted in many ways. Although the legislation guarantees compensation for such restrictions, evaluation and payment procedures have not been developed, and therefore compensation is not provided. The land restitution never took place in Belarus, and it is not expected to happen in the foreseeable future.

The environmental protection in the country is coordinated overall by the Ministry of Natural Resources and Environmental Protection (Ministry of Environment). A large portion of biodiversity management tasks are also allocated to the Ministry of Forestry. In 1994 national parks and natural reserves were transferred from 
the Ministry of Environment to the Presidential Management Department. For other governmental agencies as well as the public and citizens organizations, the transfer resulted in reduced access to information about the management activities within these protected areas.

Table 2. Categories of Specially Protected Natural Areas defined by the Belarusian Act on Specially Protected Natural Areas (sources: Act on Specially Protected Natural Areas, 1994; Ministry of Environment, 2010).

\begin{tabular}{|c|c|c|c|c|}
\hline Category & Functions & Management & $\begin{array}{l}\text { Area } \\
\text { (thousand } \\
\text { ha) }\end{array}$ & $\begin{array}{l}\text { Share } \\
\text { in total } \\
\text { protected } \\
\text { area }(\%)\end{array}$ \\
\hline
\end{tabular}

National Preservation of natural park ecosystems and objects. Restoration of disturbed ecosystems with high ecological, historical, cultural, and aesthetic values, and their sustainable use for the purposes of environmental research, education, health, and recreation.

\begin{tabular}{|c|c|}
\hline $\begin{array}{l}\text { Reserve } \\
\text { (zapavednik) }\end{array}$ & $\begin{array}{l}\text { Preservation of natural } \\
\text { ecosystems and objects. } \\
\text { The research of the gene } \\
\text { pool of flora and fauna } \\
\text { and of typical and unique } \\
\text { ecological systems and } \\
\text { landscapes. }\end{array}$ \\
\hline
\end{tabular}

Preserve Preservation, reproduction, (zakaznik)

Nature monument

\begin{abstract}
A legal entity is set up to manage the area. The land of national parks is in permanent use by the managing entities and/or other land users and land owners. There is functional zoning.
\end{abstract}

A legal entity is created to manage the area. This entity cannot be a profitgenerating organization. All zapavednik land is excluded from economic use.

No legal entity is created to manage the area.

The lands of zakazniks remain in permanent use and/or private ownership unless land users and landowners are violating the protective regime set up by the statute documents.

Zakazniks can be of national or local significance.

Land patches adjacent to nature monuments may remain in permanent use or private ownership. No legal entity is established to manage these areas. There are national and local monuments of nature. with special ecological, historical, cultural, and aesthetical features for future generations. There are three types of nature monuments: botanical, hydrological, and geological. 
Protected natural areas cover approximately 7.6\% of Belarus (Ministry of Environment, 2010). Table 3 presents changes in the number and area of protected natural areas. The reasons behind the increase of the size of protected areas in 1995-2005 are related to an abandonment of military grounds and some low-productive or remote agricultural areas, which were often converted to zakazniks. Despite a slight decrease in the area of special protected national areas (SPNAs) after 2005 caused by the liquidation of several biological zakazniks (Zenina, 2009), as we will discuss later, biodiversity conservation was becoming a higher priority in the national policy. This also explains the growth observed in $2000-05$.

Table 3. Change of the number and area of specially protected natural areas in $1980-2010$ (excluding nature monuments and local zakazniks) (sources: 2006 Second National Communication of Belarus, UNFCCC, Minsk; Ministry of Environment, 2010).

\begin{tabular}{|c|c|c|c|c|c|c|c|}
\hline \multirow[t]{2}{*}{ Parameter } & \multicolumn{7}{|l|}{ Year } \\
\hline & 1980 & 1985 & 1990 & 1995 & 2000 & 2005 & 2010 \\
\hline Number of sites & 58 & 63 & 67 & 80 & 102 & 104 & 89 \\
\hline Area (ha) & 884600 & 882900 & 900700 & 799300 & 974400 & 1416400 & 1315400 \\
\hline $\begin{array}{l}\text { Percentage of } \\
\text { country's area }\end{array}$ & 4.2 & 4.2 & 4.3 & 3.8 & 4.7 & 6.8 & 6.3 \\
\hline
\end{tabular}

\section{Characteristics of the policy change}

\subsection{Introduction of market governance}

After the political transformation the Soviet economy collapsed and the financing of protected areas decreased dramatically. From 1991, when the Belarusian state emerged, markets became a necessity for the management of protected areas in order to survive. An emphasis was timber production and tourism, including hunting. These activities were, however, kept within limits set up by relevant legislation where possible.

In 1994 the Presidential Management Department took over the management of national parks and zapavedniks. Initially not much changed, but from 2001 the protected areas were required to generate profits, and this demand increased every year. Currently, there are a few agencies designated to coordinate biodiversity conservation in Belarus. These agencies have different purposes: profit making in the case of the Presidential Management Department; forest management by the Ministry of Forestry; and environmental protection by the Ministry of Environment and the State Inspectorate. The legislation underlines the need for close cooperation and coordination between each agency, but this does not often happen. Kozulko (2005) and Parnikova (2008) point out that the subordination of the management to such a business-minded body as the Presidential Management Department leads to multiple violations of conservation regimes.

Industrial facilities, tourism activities, and other services in national parks and reserves are run by the Presidential Management Department. Park managers, acting on its behalf, are very active in the development of business projects with a particular focus on tourism (including game tourism with increasingly developing flow-line production features), logging operations, food production, and woodwork. In fact, logging and wood products have become central to the activities of national parks in Belarus. According to Zenina (2003) and Kozulko (2005) the park management bodies have launched large-scale timber-harvesting operations under the cover of sanitary felling. After new woodwork production lines were launched in the national parks Belavezhskaya Pushcha and Pripyatsky, more forested areas were transferred from the Ministry of Forestry to the Presidential Management Department to secure timber supply. 
For instance, the area occupied by the national park Pripyatsky increased by three times. A good illustration for increased use of parks for wood products is the Pripyatsky park's webpage (http://www.npp.by/) which contains exhaustive information about wood products manufactured there. Information about research, a declared core activity, is given much less space than specifications of ecologically safe parquet manufactured by the park.

Smaller-scale tourist facilities can be privately owned-for example, agro/ecotourism infrastructure. The latter is even supported by the government and (in cooperation with the government) by international donors [eg Global Environmental Fund (GEF), UN Development Program (UNDP), Technical Aid to the Commonwealth of Independent States (TACIS), and the Interregional Cooperation Program]. These facilities are run on small privately owned land plots that surround houses in the villages situated within or next to the parks' boundaries.

The Ministry of Environment is designated by legislation as a chief supervisory body where environmental protection is concerned, and should act to stop an overuse of natural resources in protected areas. However, our interviewees pointed out that the ministry has limited capacities compared with the Presidential Management Department and, even though there are quite a few complaints, they cannot be expected to intervene. This may be a result of the considerably higher position of the Presidential Management Department in the informal hierarchy of governmental bodies.

Compensation schemes are new elements of market governance that appeared after the change and separation from the Soviet Union. According to the new legislation, damages made by protected species are subjected to compensation. Nevertheless, owing to gaps in the executive law, according to the knowledge of our interviewees, compensation was never paid. As pointed out by an interviewee from the Bioresource Research Centre, "it is only written that losses should be compensated, but there are no working mechanisms, nobody even tried to do it."

\subsection{Increasing role of local communities}

Public environmental awareness is increasing due to easier access to information since the early 1990s (eg Internet, satellite television channels), increased education level, and the rise in private property. Property ownership improves perception of the value of the environment. Big disasters, such as Chernobyl, and their long-term negative consequences have also played a role. However, there are sill institutional gaps that make the organization and coordination of protest actions difficult. A professor of law from the Belarusian State University made the following statement:

"we notice that the public has a tendency to become more active, but they are not always able to use legal tools. There is a lack of a good institutional basis: consultancies, organizations providing high-quality help ... here there is a need in the 'advocacy' process, promotion of public interest."

A recent example of the increasing public environmental awareness is a campaign by people from the district of Pukhavichy (Minsk region) against an agrochemical production facility (AvgustBel) to be constructed in the neighborhood. Despite constant administrative pressure, potential danger of loss of jobs, penalties being imposed on activists, etc, people continued to protest. A few thousand signatures were collected against this project (close to $50 \%$ of the local electorate), a few street actions were held (broken up by the police; activists charged as participants of an unauthorized gathering), and a meeting organized by local authorities failed with locals walking out because the officials present (including a minister) had refused to have any dialog. Nevertheless, the logistics of the campaign show that if nothing really extraordinary 
happens (though these vigorous protests are extraordinary in themselves) the facility will be constructed anyway, as apparently big economic interests are involved.

Community protests were also organized to protect the Sevastopalski City Park in Minsk (Karol, 2008). The city of Minsk has attempted a few times to reduce the park's area in order to make space for a highway or some other construction. Interestingly enough, every time this happens the locals manage to assert their rights for green surroundings. A possible explanation is that many apartments in the neighborhood have been historically occupied by, mostly retired, staff from public prosecutors offices. These former officials have a broad knowledge of the procedures and possible legal tricks that could be used and this may explain their success. It is remarkable that they usually appeal to the Act on the Address of Citizens (1996) which guarantees that any citizens' appeal to any governmental agency shall be properly examined and answered within a firmly set term. This Act was introduced by the President and was considered by many as a populist gesture, but in this instance it has worked in the citizens' interests.

Local communities participated further in protesting against intensive logging in Belavezhskaya Pushcha (Kozulko, 2005), but in most cases they do not have enough knowledge to appeal to relevant legislation. Such legislation includes the Aarhus Convention (1998) on Access to Information, Public Participation in Decision-making, and Access to Justice in Environmental Matters. The Convention was ratified by Belarus in 2000 and can be used by Belarusians as a legal basis in asking for more information about governmental decision making. However, these cases are still rather exceptional. In many cases public participation is very had to initiate. Public meetings are almost impossible due to the law that prohibits unapproved meetings. Furthermore, according to the Act on Gatherings, Meetings, Street Processions, Demonstrations, and Picketing (1977), local meetings are considered as representative of local population only if they are attended by over $25 \%$ of local permanent residents over 18 -years old, and are convened by local governments or upon the initiative of at last $10 \%$ of local permanent residents aged over 18 .

\subsection{Emergence of independent nongovernmental organizations}

Although scientists were, for a long time, the only formal group of nonstate actors included in consultations and political decision making, this involvement increasingly became a formality: understandably, scientists want to secure governmental research funding, which in most cases is the only funding opportunity available, and they often tend to compromise. However, research departments of SPNAs (including national parks) are losing their importance (Parnikoza, 2008; Zenina, 2003).

In order to decrease the direct dependence on governmental funds and to ease access to international assistance and cooperation programs, some scientists working on internationally attractive topics have set up NGOs or reoriented existing organizations. these are so-called 'research' NGOs, usually associated with a research institute or department (even if the NGO has a national status). Good examples are Bird Protection in Belarus and the National Geographical Society. Some of these NGOs can be very successful with fundraising. Research NGOs are trying to avoid any suggestions of criticizing governmental policies where possible, because they either depend on international assistance, or are hosted by a governmental institution. International assistance requires them to register with the government and normally needs endorsements from The Ministry of Environment.

Other NGOs can be referred to as 'activist' NGOs. Activist NGOs manage to get support from international or national sources without registration, or survive without any external support. These NGOs are either registered as legal entities in Belarus and 
operate on the verge of being closed down, or manage to work without support at the risk of being persecuted for "activities on behalf of an unregistered organization" (Criminal Code of the Republic of Belarus, 2009), which leads to imprisonment in Belarus. An example is the NGO Belavezhskaya Pushcha-21st Century which runs a very successful webpage (http://bp21.org.by) and campaigns against current management practices in Belarusian SPNAs.

The last group of NGOs are so-called 'governmental' NGOs. These organizations were partly established in Soviet times, and since then have served as departments of governmental agencies performing functions outsourced by them-for example, issuing hunting or fishing licenses, as done by the Society of Hunters and Fishers. Although these organizations are formally NGOs, in fact they are fully controlled, or rather run, by the government.

The research and activist types of NGO have to struggle for their survival. They need to comply with an increasing number of rules and regulations ranging from requirements for their office (eg having a separate entrance from the street and complying with many specific requirements to fire and sanitary safety etc rather than being registered as a housing unit) to their eligible activities. The government strongly controls their budgets.

NGOs are nevertheless still tolerated since they are recognized as an important attribute of an open society which improves the image of the country in foreign politics. Representatives of NGOs are often called to attend meetings with international guests. Furthermore, there can be a need to create a competition when distributing international funds made available to NGO initiatives within priority areas identified by the government, or to invite NGO representatives for consultations that formally require (eg under international regulations or conditions of cofunding) participation of nongovernmental institutions. In the end, and perhaps most importantly, NGOs are still considered relatively harmless and can be easily closed down if they become too radical.

Despite this, even loyal NGOs are regarded as potentially rebellious, simply because they are not governmental. A representative of the NGO Geographical Society of Belarus stated that the broader public shares a view supported by their lifelong experience: that the easiest (and often the only possible) way to deal with the government is to apply small trickery and half truth rather than to become a member of an NGO.

As a representative of the NGO Ecopravo stated:

"the legal situation of NGOs is getting worse. Fewer and fewer of them remain, and those which remain are not always able to pay rent, as rent fee rates are increasing. They cannot defend citizens due to the deficient legislation that allows NGOs only to defend the rights of their own members, but not of others. The regulation also stipulates that new members can be enrolled only on the meetings of NGOs' governing bodies; and if you want to hold such a meeting you should inform the authorities about the meeting time and venue two weeks prior to the meeting. So you can imagine, how difficult that gets, especially if an urgent action is needed ..." It is worth mentioning that, but for a few exceptions, NGOs usually prefer not to disclose information on their current activities and, in particular, fundraising opportunities. The same applies to the environmental research community, which is very segregated. The public, in particular older people, do not usually trust NGOs and any initiatives, actions, or campaigns that take place to outwit the government. That makes it somewhat difficult for NGOs to approach other stakeholder groups. 
If fulfilling international agreements requires involvement of nonstate actors, only scientists or government-friendly NGOs are invited, which makes way for 'false participation'. As the professor of law from the Belarusian State University stated:

"they acknowledge the [Aarhus] convention in the ministry, but at the same time they have learned mimicry. So if there is a discussion they invite loyal NGOs, or state-controlled NGOs, and have even created a number of them for this purpose."

\subsection{Increasing role of international organizations and funds}

Belarus is a beneficiary of environmentally oriented international funds, such as from the World Bank, the GEF, the UNDP, funds of UN conventions (eg the Ramsar), the Food and Agriculture Organization, and TACIS. The funded projects certainly had an impact on existing legislation and, in particular, conservation practices. For example, EU TACIS-funded projects mostly focused on water management, environmental monitoring, waste management, circulation of chemicals, waste water treatment facilities, etc.

Most of the international granting activities are coordinated or advised by the Ministry of the Environment or other governmental institutions (eg GEF grants), and all forms of international assistance should be registered by the government. This registration, however, is not necessarily granted. Funds are distributed among a limited number of NGOs that are loyal to the government. Heads of these NGOs often hold key positions in organizations that are subordinate to the Ministry of the Environment (Kozulko, 2005). Similar arguments are raised by Falaleeva and Rauschmayer (2009) who evaluate the outcomes of a World Bank Biodiversity Project carried out in Belavezhskaya Pushcha National Park in 1992-97. The authors point out that, in a country with strong traditions of centralized top-down governance such as Belarus, international aid projects are unlikely to be a success without active support of governmental authorities. Nevertheless, the involvement of the government also leads to an unbalanced representation of stakeholders and, in general, to a weaker role of NGOs and local actors as partners for donor organizations. This is due to the fear of international managers that by involving a large number of nongovernmental stakeholders they will lose the support of government officials. Another reason can be that cooperation with a higher number of actors usually requires additional effort. The interference by high-level government officials is often purposely tolerated by international organizations since it guarantees a 'smoother' and quicker project implementation (Falaleeva and Rauschmayer, 2009).

A new EU neighborhood policy is currently being set up. It will replace existing TACIS programs and promises to be more specific in terms of priorities set by the EU. Belarus ratified a number of international environmental agreements, including the Kyoto Protocol, the Helsinki Convention, and the Aarhus Convention. One of our interviewees, a professor of law from the Belarusian State University, mentioned that the main incentive to ratify international agreements or conventions is the availability of technical assistance, "because unfortunately Belarus is not rich enough to pay for the quite expensive environmental protection." However, ratification also depends on the initiative of certain people from the Ministry of the Environment. If someone identifies an opportunity to get either financial or expert help by entering international agreements, they encourage the government to sign the agreement through the minister or viceminister.

Furthermore, UNESCO recognition and diplomas from the Council of Europe are important drivers. For instance, the Belavezhskaya Pushcha received a diploma in 1997, which was extended by the Council in 2002 but not renewed in 2007, because it did not 
have a management plan. To address this Belavezhskaya Pushcha commissioned the management plan submitted to the Council in 2009. Nevertheless, the diploma has not been renewed, this time because of the negative reviews of the new management plan.

\section{Evaluation of the policy change process}

\subsection{Perception of change by stakeholders}

The strongest criticism expressed by interviewees relating to the biodiversity governance refers to the lack of control and monitoring of the protected areas under the Presidential Management Department. The changes involving democratization and decentralization are mostly perceived as positive and having positive effects on environmental protection. In particular, the influence of international organizations and international cooperation is seen as an important opportunity. International programs are often sources of additional funding for the state administration which is thus usually eager to comply with the program requirements.

Nevertheless, impacts of many international projects are only short term and the funds are often spent on business trips and office equipment with no long-term impacts. Our interviewees particularly criticized international projects which are carried out by external experts and which are concluded with reports that have not real impact.

Practically all the interviewed stakeholders hope that the changes will empower them to gain independence from the Presidential Management Department. They hope it would improve public awareness, the quality of the environment, and in many cases give them more income, financial support, or development opportunities. A representative of the Kamianec District Council pointed out that, as a result of cooperation within the Euroregion that involved national parks and local communities, road signs and information boards are installed. A representative of Belavezhskaya Pushcha said that international projects are regularly implemented in the park which contribute to the restoration of the environment. For instance, as a result of a project funded by the Agricultural Ministry of the Netherlands, some wetlands in the park were restored.

The pressure of the international community is seen as necessary to provide information for citizens and to involve the ministries in international projects, making them feel that what they are doing is important. Although there are no actual sanctions for not fulfilling international agreements, reputation is also important. The professor of law from the Belarusian State University stated that

"the political image of the country also means a lot, because you will be told that if you do not comply with an international agreement, in a broader sense you do not comply with the main principle of Vienna convention that says that all agreements should be implemented. It is a slap in the face of the country."

Institutional gaps are often compensated for by informal practices. On the international level, NGOs from Ukraine or Poland represent banned NGOs from Belarus. On the local level, despite the lack of formal communication channels, local authorities have informal contacts with the national park's administration and cooperate in various educational and other activities. For instance, local inhabitants have informal rights to use dead wood and hay in some parts of the protected areas. In the Belavezhskaya Pushcha, although there are no formal cooperation channels between the national park administration and local authorities, the park's general director was elected as one of thirty-seven members of the district council to facilitate such cooperation. As a representative of the Kamianec district stated, "cooperation is very regular for us; for instance the National Park has a school bus collecting children from remote areas. ... They also participate in our activities, including financial assistance to certain persons." 
Another informal practice accommodating the lack of mechanism to compensate for land requisitioned for protected areas is to simply exclude private land from such protected areas. A researcher from the Bioresource Research Centre reported that,

"because we do not have compensation mechanisms, when drawing the boundaries of special protected areas, lands of settlements, summer house cooperatives, and engineering constructions are excluded. They have very complicated contours with lots of holes."

\subsection{Level of political conflict}

As NGO representatives report, the conflicts are, in particular, related to the division of responsibilities between various government agencies and lack of control over the Presidential Management Department. However, although the interviewees from the Ministry of Environment mention disagreement, they do not intervene in the conflicting issues and submit to the presidential administration. When we inquired into overlogging in the Belavezhskaya Pushcha, the interviewed representative of the conservation inspectorate insisted that in her opinion there were no problems. The interviewee also said that, according to the legislation, local government also had rights to control compliance with environmental legislation. However, they did not do so since they lacked political will and personnel to take responsibility for it.

An interviewed research officer from the Bioresource Research Centre reported that there are conflicts between managers of protected areas who belong to the Presidential Management Department and local land users. Since the Presidential Management Department has financial and administrative power much greater than that of other actors, they do not treat other land users or local governments as partners. There are also conflicts within the Presidential Management Department. One such conflict is between national parks' directorates tasks. On the one hand they exist to protect nature, but on the other they are under pressure to maximize income generated from the protected areas. Thus they develop agricultural, hunting, and logging activities within parks and build tourist infrastructure themselves within protected areas rather than contracting with outside businessmen and tourist agencies. A representative of Belavezhskaya Pushcha referred to this situation:

"we still have a planned economy in our country. It means that we get certain plans (ie assignments) for earning money from higher levels. ... You see the management of the National Park is often criticized for cutting a lot of trees and so on. But it is not an issue. We just have the plan. If we do not comply with it, then we are punished or fired. Maybe the director does not even want to cut a lot [of trees], but he has to do so. They only way to escape this is to transfer land to the forbidden zone as much as possible."

Nevertheless, transference of all areas to the forbidden zone would disable any kind of human intervention there.

The Presidential Management Department controls all the units subjected to it and all the information flows. The interviewed representative of Belavezhskaya Pushcha said,

"all National Parks are subordinated directly to the Management Department of the President. If all other forests are managed by the Ministry of Forestry, National Parks are managed by the Management Department. Accordingly, this makes a lot of difference. On the one hand we are well backed by the State budget, on the other, there is a stricter regime, eg concerning relations with media, contacts with the public." 
There are also a few reports about social conflicts at protected areas: Zenina (2003), Kozulko (2005), and Parnikoza (2008) report mass dismissals of local contracted workers, forest officers, and research staff. In their place, people from other parts of Belarus or even abroad are contracted. The message transmitted in these reports is that being 'foreigners' to these forests, the newcomers do not care about the environment and do not feel it is wrong to cut trees in natural reserves. This was probably the reason for replacing local people with 'strangers', who are easier to manipulate. Some other conflicts (destroying crops, etc) also exist, although have not as yet been broadly publicized.

Since the state owns most of the land, however, it is relatively easy to establish new protected areas. In neighboring Poland enlargement or establishment of national parks is usually strongly opposed by local communities who are afraid of hampering development activities. On the contrary, in Belarus such protests do not occur, and local inhabitants usually support the establishment of protected areas. Local governments even provide a protection status to valuable local environmental sites within their administrative borders. The interviewed members of local governments stressed that for the local community the parks in their area are very important tourist attractions and they see nature as an asset.

Nevertheless, a source of potential conflict between local communities and protected areas administration is a lack of enforcement of compensation for damage by wild animals. As a representative of the Kamianec District Council pointed out,

"ungulate animals are to abundant, and a portion of agricultural lands has been transferred to the Park. Some animals are protected, some are hunted. Nowadays they also appear on nearby crops and cause damage, both to individuals and agricultural companies. We are now coming up with proposals to the Administration of the President in order to find optimal solutions."

Illegal NGOs and activists are clearly in conflict with both the government and the Presidential Management Department. Interestingly, in order to get into the park and inspect activities, the activists often have to conspire with the local population within the national park. The activists often witness many examples of overuse of the park's resources by locals, but they never report this officially.

\subsection{Uncertainties related to the policy change}

Uncertainties are related to the reaction of the Presidential Management Department. It is still a highly centralized and very much top-down system. Practically all actors bear in mind that if they are openly against the current governmental policy they may lose their jobs or be prosecuted.

An interviewee from the Bioresource Research Centre pointed out uncertainties related to the availability of the public funding both from the Presidential Management Department and from the government. Certain categories of protected areas such as, for instance, so-called SPNAs have very small budgets and they are under threat that the funding will be discontinued.

As personal connections and relationships with the President and people close to him are very important, a big source of uncertainty is related to who will be supported by him, and for how long. People favored by the President do not have to comply with the law and attempts to bring an action against them would not help. A representative of the NGO Belavezhskaya Pushcha-21st Century mentioned that citizens, national, or international organizations may complain, but the complaints can be useless if the person or agency mentioned in the complaint enjoys some support from the presidential administration. According to the interviewee from the same NGO, the law monitoring protected natural areas is not enforced by the government due to the 
uncertainty of the reactions of the President's administration, "although there is a monitoring law, the people from the Ministry [of the Environment] are afraid of touching this." The national legislation recognizes the Ministry of Environment as an authority responsible for the monitoring and coordination of nature protection in all the protected areas, including the areas administered by the Presidential Management Department. Nevertheless, owing to the fear of upsetting someone potentially close to, or favored by, the presidential administration, the monitoring is practically nonexistent and the law has never been properly enforced.

Sources of other uncertainties are global environmental changes and, in particular, climate change. As expressed by the interviewee from the Ministry of the Environment, climate change affects many fields of the economy such as energy, agriculture, and forestry. The ministry and national science institutes have limited capacity to deal with these impacts. The authorities are thus more open to the advice and assistance of international organizations and experts.

\subsection{Perspectives on the future of the process}

Weak monitoring and law enforcement, as well as practically monopolistic control of the Presidential Management Department over protected areas, suggests that, although there are clear signs of emerging multilevel governance, the changes are slow. In the Soviet times there were no consultations with locals and there were no independent NGOs. In comparison, what is happening now is very different. At the majority of levels new actors appear and demand action.

Practically all interviewed actors see that future changes are inevitable; they clearly see their benefits and they are not afraid of talking about them. The representative of the Belavezhskaya Pushcha, although he is part of the Presidential Management Department, stated,

"I believe the most efficient projects are where representatives of various parties are involved, not only from one institution, but from several institutions, with joint control over the implementation. It is important because it often happens that the project is formally implemented, the report is written, and that's it, and the country cannot really benefit from any tangible project outputs. ... We have a big problem with NGOs in our country in general, because they are almost absent. ... You know, there is a proverb that one head is good to have, but two heads are even better. ... It is always good to listen to different opinions."

Despite the fact that NGOs are not encouraged to be active, their representatives are aware, and proud of, the benefits generated by their action. Although the head of the Belavezhskaya Pushcha-21st Century NGO lost his job because of his activism, and the presidential administration keeps prosecuting him, he is proud he changed history and helped to save the national park:

"I can say now that our activity changed the history of Belavezha Forest. If there had been none of our activities the history could have been different. Due to our activities, the history has radically changed. ... Another activist from Minsk wrote a letter to the UNESCO about the world heritage being in danger. After that mission a group of experts were sent to control the Park, volunteers visited the Park. ... the UNESCO experts accepted our point of view and the Park administration was afraid to be scandalized ...."

The NGO also provided information to the Council of Europe to show that twenty recommendations they gave regarding how to maintain and conserve the park were broken by its administration. It was an international scandal which undermined the reputation of the country - thus the administration is afraid of breaking the international agreements again. 
To sum up, we believe that the increasing number of international programs as well as inclusion of nonstate actors and active involvement of citizens and local governments will continue to improve monitoring and enforcement of environmental legislation. Support of international organizations, particularly for local activists who bear high personal costs of their activism, could strengthen and speed up these positive tendencies.

\section{Conclusions}

We analyze an emergence of multilevel biodiversity governance in Belarus. The country has been under a strongly centralized political regime since 1994. The Presidential Management Department took over the management of national parks and some other protected areas in the country. This seriously diminished access to information about the state of the biodiversity and management activities within the protected areas under its administration.

Nevertheless, mostly due to a combination of external and internal factors, we observe that the Belarusian hierarchical and centralized political system is slowly opening up and is sharing some of its powers with nongovernmental actors. Nongovernmental stakeholders are becoming more involved in the decision making and governance of natural resources.

In the paper we characterize the policy changes that entail an introduction of the elements of market governance in protected areas, collaboration of protected areas' administration with local communities, an emergence of independent NGOs, and an increasing role of international organizations and funds. In the evaluation of the policy changes we compare perceptions of the changes by different stakeholder groups, and assess the level of political conflict and uncertainties surrounding the changes. Our empirical evidence is based on literature and document review, as well as on in-depth interviews carried out with key stakeholders.

There are clear signs of emerging multilevel environmental governance in Belarus. The signs observed include the dispersion of governmental authority to generalpurpose territorial jurisdictions and empowering of local governments characterized by Hooghe and Marks (2003). There is also an increasing participation of nongovernmental actors in political decision making, which is identified by Bache and Flinders (2005) as a key characteristic of multilevel governance. What is nevertheless different from Western democracies and findings reported - for example by Deyle (1994), Berry (1994), and Vo $\beta$ (2007) - is that this process is weakly supported by the development of corresponding legislation that would recognize and regularize interactions with new actors and statutory powers. It is even less supported by institutional mechanisms which may not be present even if relevant legislation is formally in force. The policy innovation in the Belarusian biodiversity protection is not an outcome of a consciously designed and implemented process supported by the development of subsequent legal frameworks, but rather a necessity and an outcome of the coping strategies taken by governmental agencies. For instance, market instruments used in national parks have been developed in response to an increasing pressure from the Presidential Management Department to deliver profits. Ad hoc public participation in decision making in the national parks is often organized in order to comply with the requirements of international programs. It is also required where organizations will release their funds, or other forms of support, only if nongovernmental actors are participating.

Apparently, these developments were not followed by the introduction of legal standards and procedures ensuring equal access to information and providing sanctioning tools in case of mismanagement. Innovatory practices such as the use of market instruments - for example, charges on tourist activities and permits on logging operations on protected areas - are carried out although private property and private 
companies are practically nonexistent and there is no contract law relevant to public organizations. Such a law would ensure equal access to information for all potentially interested parties, would ensure the choice of the most competitive offer, and would specify sanctions in case of misconduct. On the other hand, as we mentioned above, in a few cases some innovative pieces of legislation cannot be implemented because the relevant institutional mechanisms have not been developed. This is the case with the law on compensating damage done by wild animals, or the law on the monitoring of protected areas by the Ministry of Environment.

In Belarus newly emerging institutions recombine with the remains of the communist and the centralized autocratic political system. This is in line with the observations of Kluvánková-Oravská et al (2009) for other transition countries. There are strongly visible power asymmetries between the Presidential Management Department and other actors, which generates a fear and an expected uncertainty in possible interactions with the presidential officials; it is believed that disagreements with the department may result in a cut in public funding for research institutions, lost support for the registration, and implementation of international projects, closing down of NGOs, and loss of jobs for individuals.

Nevertheless, it is remarkable that all interviewed actors perceive the multilevel policy changes as inevitable and the interviewees believe that the changes lead to an improved quality of the environment through stronger monitoring and more transparent decision making in protected areas. Various forms of support from international organizations are required to ensure the continuity of this process.

Acknowledgements. The research was supported by the 'Multilevel Governance of Natural Resources: Tools and Processes for Biodiversity and Water Governance in Europe' project, funded within the FP6 Program of the European Commission, as well as by a grant from the CEU Budapest Foundation (Budapest Közép-Európai Egyetem Alapítvány). We acknowledge Tatiana KluvankovaOravska and Veronika Chobotova for the methodological guidelines and comments on the research. We also acknowledge comments on the paper given by Anna Wesselink, Violeta Dirimanova, and anonymous referees.

\section{References}

Armitage D, 2008, "Governance and the commons in a multi-level world" International Journal of the Commons $27-32$

Bache I, Flinders M, 2005, "Multi-level governance: conclusions and implications", in Multilevel Governance Eds I Bache, M Flinders (Oxford University Press, New York) pp 195-206

Banaszak I, Beckmann V, 2008, "Incentive structure in public policies-example of the law on producer groups in Poland" Society and Economy 30 79-92

Berry F S, 1994, "Sizing up state policy innovation research" Policy Studies Journal 22442 - 456

Bosse G, 2009, "Challenges for EU governance through neighbourhood policy and eastern partnership: the values/security nexus in EU-Belarus relations" Contemporary Politics 2 $215-227$

Bosse G, Korosteleva-Polglase E, 2009, "Changing Belarus? The limits of EU governance in Eastern Europe and the promise of partnership" Cooperation and Conflict $2143-165$

Bräuer I, Mussner R, Marsden K, Oosterhuis F, Rayment M, Miller C, Dodokova A, 2006, "The use of market incentives to preserve biodiversity: final report", project under the Framework Contract for Economic Analysis ENV.G.1/FRA/2004/0081, http://www.naider.com/upload/ mbi.pdf/

Chobotová V, 2007, "Evolution of institution for sustainable tourism in the context of transition process of Slovakia", WP 5, Institute for Forecasting, Slovak Academy of Sciences, Bratislava

Dahl R A, 1971 Polyarchy (Yale University Press, New Haven, CT)

Deyle R E, 1994, "Conflict, uncertainty, and the role of planning and analysis in public policy innovation" Policy Studies Journal 22457 - 473

Dryzek J S, 1997 The Politics of the Earth: Environmental Discourses (Oxford University Press, New York)

Elander I, 1997, "Between centralism and localism: on the development of local self-government in postsocialist Europe" Environment and Planning C: Government and Planning 15143 - 159 
Falaleeva M, Rauschmayer F, 2009, "Positive evaluations may be shortlived: on outcomes and processes of a World Bank biodiversity project in a post-communist country", DP 3/2009, Helmholtz-Zentrum für Umweltforschung, Leipzig

Fiorino D, 1989, "Environmental risk and democratic process: a critical review" Columbia Journal of Environmental Law $14501-547$

Gatzweiler F, Hagedorn K, 2002, "The evolution of institutions in transition" International Journal of Agricultural Resources, Governance and Ecology $237-58$

Hodgson G M, 2004 The Evolution of Institutional Economics: Agency, Structure, and Darwinism in American Institutionalism (Routledge, London)

Hooghe L, Marks G, 2003, "Unraveling the central state, but how? Types of multi-level governance" The American Political Science Review 97233 - 234

Karol M, 2008, "Zhars'ci vakol Sevastopalskaha parku” [Passions over Sevastopol park], http://www.polskieradio.pl/zagranica/news/artykul85280.html

Kluvánková-Oravská T, Chobotová A, 2006, "Shifting governance. Managing the commons: the case of Slovensky Raj National Park" Sociologia 38221 - 244

Kluvánková-Oravská T, Chobotová V, Banaszak I, Trifunovova S, Slavikova L, 2009, "From government to governance for biodiversity: the perspective of central and east-European transition countries" Environmental Policy and Governance 19186 - 196

Korosteleva E, 2009, "The limits of EU governance: Belarus' response to the European neighbourhood policy" Contemporary Politics $2229-245$

Kozulko G, 2005, "Zelenyj bazaar, ili pochemu belorusskie ekologi ne podderzhali akciju v zaschitu Belovezhskoj Pushchi” [The green bazaar, or why Belarusian environmental activists do not support actions to protect the Belavezhskaya Pushcha], http://bp21.org.by/ ru/art/a051014.htm

McGinnis M, 1999, "Introduction", in Polycentric Governance and Development: Readings from the Workshop in Political Theory and Policy analysis Ed. M McGinnis (University of Michigan Press, Ann Arbor, MI) pp $1-30$

Meadowcroft J, 2002, "Politics and scale: some implications for environmental governance" Landscape and Urban Planning $61169-179$

Ministry of Environment, 2010, "Osobo ohraniaemye prirodnye territorii Respubliki Belarus" [Specially Protected Natural Areas of the Republic of Belarus], http://minpriroda.by/ru/ osob_ohran

Mnatsakanian R, 1992 Environmental Legacy of the Former Soviet Republics (University of Edinburgh, Edinburgh)

Newig J, Fritsch O, 2009, "Environmental governance: participatory? Multi-level - and effective?" Environmental Policy and Governance 19 197-214

Ostrom V, Tiebout C, Warren R, 1961, "The organization of government in metropolitan areas" American Political Science Review 55831 -842

Parnikoza I, 2008, "Sistema pryrodnyh terytoryj asablivaj ahovy Belarusi: pozirk z Ukrainy" [The system of Specially Protected Natural Areas in Belarus: a view from the Ukraine], http://h.ua/story/87219

Pickvance C G, 1997, "Decentralization and democracy in Eastern Europe: a sceptical approach" Environment and Planning C: Government and Policy $15129-142$

Pierre J, Peters G B, 2000 Governance, Politics and the State (St Martin's Press, New York)

Rauschmayer F, Wittmer H, 2006, "Evaluating deliberative and analytical methods for the resolution of environmental conflicts" Land Use Policy 23108 - 122

Rauschmayer F, Paavola J, Wittmer H, 2009, "European governance of natural resources and participation in a multi-level context: an editorial" Environmental Policy and Governance $19141-147$

Sabatier P A, Leach W D, Lubell M, Pelky N W, 2005, "Theoretical frameworks explaining partnership success", in Swimming Upstream. Collaborative Approaches to Watershed Management Eds P A Sabatier, W Focht, M Lubell, Z Trachtenberg, A Vedlitz, M Matlock (MIT Press, Cambridge, MA) pp 173 - 199

Sakovich V, 2005, "O zemelnoj reforme v Belarusi na rubezhe 20-nachale 21 vekov" Obshchestvo i Ekonomika 5108 - 124

Smith G, 2003 Deliberative Democracy and the Environment (Routledge, London)

Stavrosky D D, Kovaliov A A, 1996 Berezinsky Biosphere Reserve (Belaruskaya Encyklapedya, Minsk)

Stirling A, 2006, "Analysis, participation and power: justification and closure in participatory multi-criteria analysis" Land Use Policy 23 95- 107 
Voß J P, 2007 Designs on Governance. Development of Policy Instruments and Dynamics in Governance $\mathrm{PhD}$ dissertation, School of Management and Governance, University of Twente, Enchede

Weiner D R, 1999 A Little Corner of Freedom: Russian Nature Protection from Stalin to Gorbachev (University of California Press, Berkeley, CA)

Young O R, 2002 The Institutional Dimensions of Environmental Change: Fit, Interplay, and Scale (MIT Press, Cambridge, MA)

Zenina I, 2003, "Grimasy zapovednosti sovremennoj Belarusi" [Grimaces of wildlife protection in present-day Belarusi] Zapovednik 1, http://bp21.org.by/ru/art/a0301.htm

Zenina I, 2009, "V proshlom godu ploschad' zapovednyh territorij Belarusi umen' shilas' do urovnia 2000 goda" [Last year the total area of nature conservation areas had decreased to the same size as in 2000], http://greenbelarus.info/content/view

Zsamboki K, Bell M, 1997, "Local self-government in Central and Eastern Europe: decentralization or deconcentration?" Environment and Planning C: Government and Policy 15177 - 186

\section{Legislation}

Aarhus Convention, 1998, "Convention on access to information, public participation in decisionmaking and access to justice in environmental matters", United Nations Economic Commission for Europe, Aarhus, Denmark, http://www.unece.org/env/pp/documents/cep43e.pdf

Act of Land Property Rights, 1993 Vedamasci Viarhounaha Saveta Respublika Belarus [Act of the Republic of Belarus on Land Property Rights], 16 June, page 285

Act on Gatherings, Meetings, Street Processions, Demonstrations, and Picketing, 1997 Vedamasci Viarhounaha Saveta Respubliki Belarus [Act of the Republic of Belarus on Gatherings, Meetings, Street Processions, Demonstrations, and Picketing], 30 December, 2, page 6

Act on Specially Protected Natural Areas, 1994 Vedamasci Viarhounaha Saveta Respubliki Belarus [Act of the Republic of Belarus on SPNAs], 20 October, 35, page 570

Act on the Address of Citizens, 1996 Vedamasci Viarhounaha Saveta Respubliki Belarus [Act of the Republic of Belarus on the Address of Citizens], 6 June, 21, page 376

Criminal Code of the Republic of Belarus, 2009, Alafeya, Minsk

Land Code, 1990 Vedamasci Viarhounaha Saveta Belaruskay SSR [Land Code of the Republic of Belarus], 11 December, 2(4), page 11 
Conditions of use. This article may be downloaded from the E\&P website for personal research by members of subscribing organisations. This PDF may not be placed on any website (or other online distribution system) without permission of the publisher. 